\title{
Interpretation of Solvent Effects on Styrene/Maleic Anhydride Copolymer Sequence Distribution and Microstructure in Terms of the Bootstrap Effect
}

\author{
Citation for published version (APA): \\ Klumperman, L., \& Brown, P. G. (1994). Interpretation of Solvent Effects on Styrene/Maleic Anhydride \\ Copolymer Sequence Distribution and Microstructure in Terms of the Bootstrap Effect. Macromolecules, 27(21), \\ 6100-6101. https://doi.org/10.1021/ma00099a023
}

DOI:

10.1021/ma00099a023

Document status and date:

Published: 01/01/1994

\section{Document Version:}

Publisher's PDF, also known as Version of Record (includes final page, issue and volume numbers)

\section{Please check the document version of this publication:}

- A submitted manuscript is the version of the article upon submission and before peer-review. There can be important differences between the submitted version and the official published version of record. People interested in the research are advised to contact the author for the final version of the publication, or visit the DOI to the publisher's website.

- The final author version and the galley proof are versions of the publication after peer review.

- The final published version features the final layout of the paper including the volume, issue and page numbers.

Link to publication

\footnotetext{
General rights

- You may freely distribute the URL identifying the publication in the public portal. follow below link for the End User Agreement:

www.tue.nl/taverne

Take down policy

If you believe that this document breaches copyright please contact us at:

openaccess@tue.nl

providing details and we will investigate your claim.
}

Copyright and moral rights for the publications made accessible in the public portal are retained by the authors and/or other copyright owners and it is a condition of accessing publications that users recognise and abide by the legal requirements associated with these rights.

- Users may download and print one copy of any publication from the public portal for the purpose of private study or research.

- You may not further distribute the material or use it for any profit-making activity or commercial gain

If the publication is distributed under the terms of Article $25 \mathrm{fa}$ of the Dutch Copyright Act, indicated by the "Taverne" license above, please 


\title{
Interpretation of Solvent Effects on Styrene/Maleic Anhydride Copolymer Sequence Distribution and Microstructure in Terms of the Bootstrap Effect
}

\author{
Bert Klumperman* \\ DSM Research, P.O. Box 18,6160 MD Geleen, The Netherlands \\ Paul G. Brown \\ Department of Chemistry, The University of New England, Armidale, NSW 2351, Australia \\ Received April 19, 1994; Revised Manuscript Received July 28, $1994^{\circ}$
}

\begin{abstract}
Solvent effects on the copolymerization of styrene and maleic anhydride are interpreted in terms of Harwood's bootstrap effect. Earlier observations that this comonomer pair behaves according to the bootstrap effect are confirmed. Furthermore, solvent effects on stereochemical configuration can be interpreted in terms of the bootstrap effect as well. The observation that the $Z / E$ ratio of the anhydride units versus copolymer composition is independent of solvent is attributed to monomer partitioning between the bulk of the solution and the locus of polymerization.
\end{abstract}

\section{Introduction}

The effect of solvents on free radical copolymerization has been the subject of many studies in the past. Some years ago, it was discovered that despite the fact that apparent reactivity ratios may be influenced considerably by solvent, no such effect is observed on the conditional probabilities that determine chain growth. ${ }^{1}$ The result of this so-called bootstrap effect is that copolymers with the same overall composition have the same monomer sequence distribution regardless of the solvent employed during synthesis.

After introduction of the bootstrap effect in 1987, a few papers were published in which methods are reported to quantify the essential parameter of the bootstrap effect, the monomer partition coefficient $(K)^{2,3}$ All of these papers use monomer triad distributions as a measure for the sequence distribution in the polymer chain.

The reasoning behind the bootstrap effect is that a copolymer with a certain composition is formed at identical local comonomer ratio. The real reactivity ratios are essentially independent on the solvent. In the light of this theory, not only monomer sequence distribution versus copolymer composition should be independent of solvent but also copolymer microstructure versus copolymer composition. Recently published data on the copolymerization of styrene (STY) and maleic anhydride (MAnh) in butanone (MEK) and chloroform $\left(\mathrm{CHCl}_{3}\right)$ already provide an indication in this respect. ${ }^{4}$ The same experimental data, completed with the remaining monomer triad fractions and copolymer composition, are used to evaluate the occurrence of the bootstrap effect in terms of both monomer sequence distribution and copolymer microstructure.

\section{Experimental Procedures and Results}

STY/MAnh copolymers were prepared at $50^{\circ} \mathrm{C}$ in MEK and $\mathrm{CHCl}_{3}$ as described previously. ${ }^{4}$ STY-centered triad fractions and $Z / E$ ratios were determined from DEPT ${ }^{13} \mathrm{C}$ NMR spectra following previously published assignments. ${ }^{5,6}$ The $Z / E$ ratio is defined as the ratio of cis (zusammen) to trans (entgegen) configurations of anhydride units in the copolymer.

Abstract published in Advance ACS Abstracts, September 1 ,
Copolymer compositions were calculated from the measured STY-centered triad fractions according to a previously published method, ${ }^{5}$ using eq 1 .

$$
\frac{F_{\mathrm{STY}}}{F_{\mathrm{MAnh}}}=1+\frac{2 A_{\mathrm{SSS}}+A_{\mathrm{SSM}+\mathrm{MSS}}}{2 A_{\mathrm{MSM}}+A_{\mathrm{SSM}+\mathrm{MSS}}}
$$

$F_{\text {STY }}$ and $F_{\text {MAnh }}$ are the fractions of STY and MAnh, respectively, in the copolymer. Axsx is the surface area of the peak assigned to the XSX-indexed STY-centered triad in the DEPT ${ }^{13} \mathrm{C}$ NMR spectrum.

The experimental results are graphically shown in Figures 1 and 3 for copolymerizations in $\mathrm{MEK}$ and $\mathrm{CHCl}_{3}$.

\section{Discussion}

In Figure 1 copolymer composition $\left(F_{\text {MAnh }}\right)$ is plotted versus monomer feed composition $\left(f_{\text {MAnh }}\right)$ for the copolymerizations in both solvents. It is very clear that there is a solvent effect. Copolymers synthesized in $\mathrm{CHCl}_{3}$ have a higher MAnh content than those synthesized in MEK at equal fraction of MAnh in the feed. Apparent reactivity ratios are calculated by nonlinear least squares (NLLS) estimation ${ }^{7}$ on triad distribution and copolymer composition versus monomer feed simultaneously. The model which was used to describe the copolymerization is the penultimate unit model with the constraint of no homopolymerization of MAnh. Recently, conclusive model discrimination between the penultimate unit model and the complex participation model in favor of the former was achieved. ${ }^{8}$ The apparent reactivity ratios are $r_{\mathrm{SS}}=$ 0.018 and $r_{\mathrm{MS}}=0.050$ in $\mathrm{MEK}$ and $r_{\mathrm{SS}}=0.018$ and $r_{\mathrm{MS}}$ $=0.026$ in $\mathrm{CHCl}_{3}$.

From the variance-covariance matrix, 95\% joint confidence intervals are drawn as shown in Figure 2. Also shown in Figure 2 are the lines that indicate the boundaries between which the ratio $r_{\mathrm{SS}} / r_{\mathrm{MS}}$ varies for both solvents. This ratio was shown to be the determining factor to describe monomer sequence distribution versus copolymer composition. ${ }^{2}$ To match the experimental data in this work for both solvents, $0.2<r_{\mathrm{SS}} / r_{\mathrm{MS}}<0.6$. In Figure 3 monomer triad distributions are plotted versus copolymer composition for copolymerization in both solvents. The curves are drawn from the penultimate unit model with the constraint of no homopropagation of MAnh and $r_{\mathrm{SS}} /$ $r_{\mathrm{MS}}=0.4$. It is clear that the experimental data are described satisfactorily by the drawn curves. Hence, no 


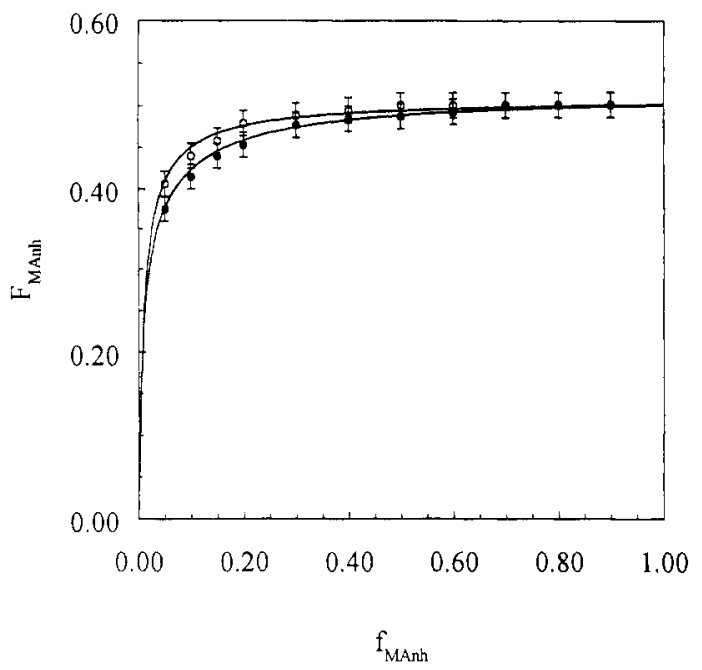

Figure 1. Copolymer composition ( $F_{\text {MAnh }}$ ) versus monomer feed composition ( $f_{\mathrm{MAnh}}$ ) of the copolymerization of styrene and maleic anhydride at $50^{\circ} \mathrm{C}$ in $\mathrm{MEK}(0)$ and in $\mathrm{CHCl}_{3}(0)$.

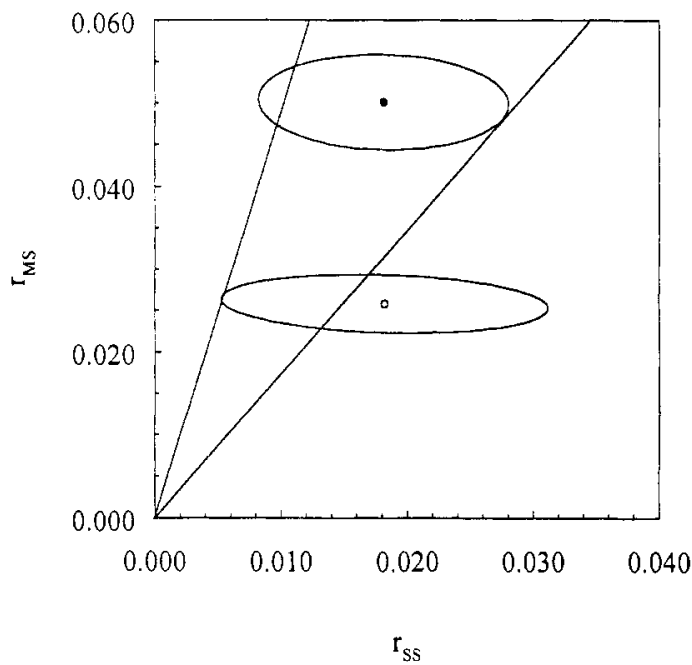

Figure 2. 95\% joint confidence interval of the penultimate unit model reactivity ratios ( $r_{\mathrm{SS}}$ and $r_{\mathrm{MS}}$ ) of the copolymerization of styrene and maleic anhydride at $50^{\circ} \mathrm{C}$ in $\mathrm{MEK}(\bullet)$ and in $\mathrm{CHCl}_{3}$ (0). Drawn lines are the boundary values of constant $r_{\mathrm{SS}} / r_{\mathrm{MS}}$ ratio, applicable to both solvents $\left(0.2<r_{\mathrm{SS}} / r_{\mathrm{MS}}<0.6\right)$.

solvent effect is observed, which is in accordance with the bootstrap effect.

In a previous publication it was shown that there is a clear solvent effect on the $Z / E$ ratio versus comonomer feed. ${ }^{4}$ Similar to the monomer triad distribution, we plot the $Z / E$ ratio versus copolymer composition as shown in Figure 4. Although the experimental data contain a relatively large error, as indicated by the error bars in Figure 4, it is obvious that one curve could be used to represent the experimental data of both solvents. This leads to the conclusion that the bootstrap effect may also account for solvent effects on copolymer microstructure in the sense of stereochemical configurations.

\section{Conclusions}

The copolymerization of styrene and maleic anhydride behaves according to the bootstrap effect when carried out in $\mathrm{MEK}$ and $\mathrm{CHCl}_{3}$. This result confirms earlier observations on the same comonomer pair in MEK, in bulk, and in toluene. ${ }^{2}$

Earlier reported solvent effects on stereochemical configurations of this copolymer ${ }^{4}$ can be interpreted in terms of the bootstrap effect as well. The $Z / E$ ratio of the

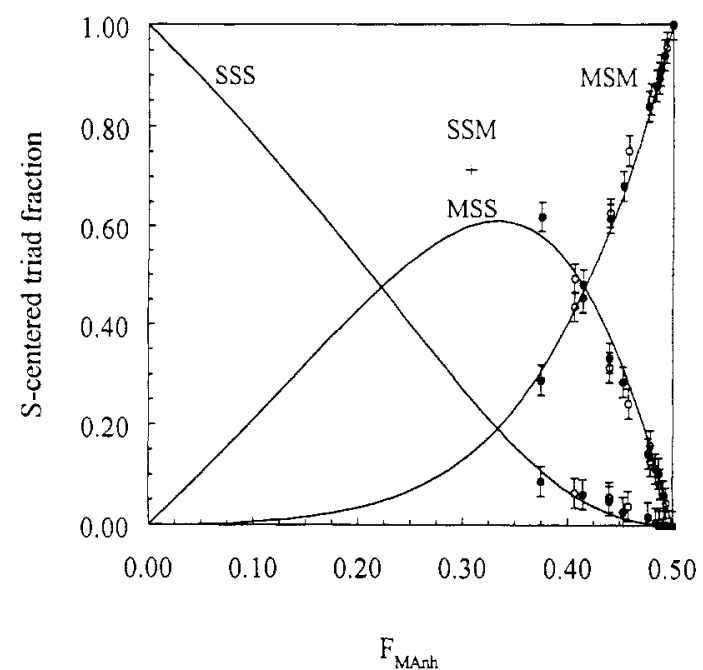

Figure 3. Styrene-centered triad distribution versus copolymer composition of the copolymerization of styrene and maleic anhydride at $50^{\circ} \mathrm{C}$ in MEK (O) and in $\mathrm{CHCl}_{3}(0)$. Drawn curves are calculated from the penultimate unit model with the constraint of no homopropagation of MAnh and $r_{\mathrm{ss}} / r_{\mathrm{MS}}=0.4$.

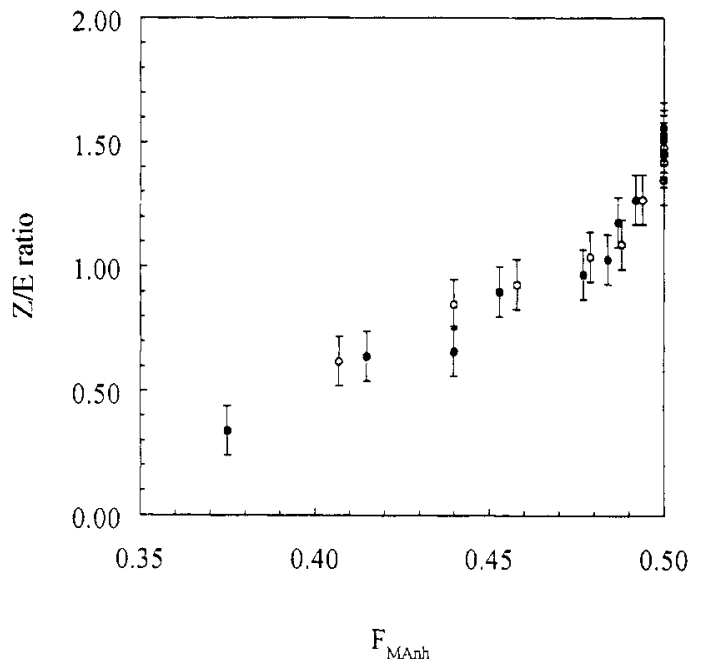

Figure 4. $Z / E$ ratio of the maleic anhydride unit versus copolymer composition of the copolymerization of styrene and maleic anhydride at $50^{\circ} \mathrm{C}$ in $\mathrm{MEK}(\bullet)$ and in $\mathrm{CHCl}_{3}(\mathrm{O})$.

anhydride units versus copolymer composition appears to be independent of solvent within the limits of experimental error. It is hypothesized that this phenomenon has the same origin as the solvent independence of monomer sequence distribution versus copolymer composition. A copolymer with a certain composition is formed at a fixed local comonomer ratio where this comonomer ratio is determined by the overall comonomer feed composition and the monomer partitioning between the bulk of the solution and the locus of polymerization.

\section{References and Notes}

(1) Harwood, H. J. Makromol. Chem., Macromol. Symp. 1987, 10/ $11,331-354$.

(2) Klumperman, B.; O'Driscoll, K. F. Polymer 1993, 34, 10321037.

(3) Klumperman, B.; Kraeger, I. R. Macromolecules 1994, 27, 15291534.

(4) Brown, P. G.; Fujimori, K. Macromol. Rapid Commun. 1994, $15,61-65$.

(5) Barron, P. F.; Hill, D. J. T.; O’Donnell, J. H.; O'Sullivan, P. W. Macromolecules 1984, 17, 1967-1972.

(6) Brown, P. G.; Fujimori, K. Polym. Bull. 1992, 27, 543-547.

(7) Britt, H. J.; Luecke, R. H. Technometrics 1973, 15, 233-247.

(8) Sanayei, R. A.; O'Driscoll, K. F.; Klumperman, B. Macromolecules $1994,27,5577$. 